\title{
Siniketun rehuhyötysuhteen perinnölliset tunnusluvut
}

\author{
Riitta Kempe ${ }^{1)}$, Ismo Stranden ${ }^{1)}$, Teppo Rekilä ${ }^{2}$, Nita Koskinen ${ }^{2)}$ ja Esa Mäntysaari ${ }^{1)}$ \\ ${ }^{1)}$ MTT, BEL, Biometrinen genetiikka, H-talo, 31600 Jokioinen, riitta.kempe@mtt.fi \\ ${ }^{2}$ MTT, Kotieläintuotannon tutkimus, Turkiseläintalous, PL 44,69101 Kannus, etunimi.sukunimi@mtt.fi
}

\section{Tiivistelmä}

Rehu on turkistuotannon suurin kustannustekijä ja siinä saavutettavat säästöt alentavat merkittävästi turkisten tuotantokustannuksia. Kotieläinten parempi rehuhyötysuhde vähentää myös ympäristöpäästöjä. Sinikettujen rehuhyötysuhde tai rehunkulutus eivät ole nykyisissä valintaohjelmissa mukana jalostettavina ominaisuuksina. Tämä johtuu siitä, että yksilöllistä rehunkulutusta on ollut vaikea mitata suuresta yksilömäärästä. Rehunkulutustietojen kerääminen on tullut mahdolliseksi uusien yksilöllistä rehunkulutusta mittaavien automaattisten ruokintajärjestelmien myötä. Rehuhyötysuhteen laskeminen vaatii rehunkulutustietojen lisäksi tiedon eläimen painonmuutoksesta vastaavana ajankohtana.

Tutkimuksessa selvitettiin rehuhyötysuhteen ja kasvunopeuden periytyvyys ja perinnölliset yhteydet eläimen kokoon. Aineisto koostui 2076 siniketusta. Sukulaistiedot saatiin Suomen turkiseläinten kasvattajainliiton ylläpitämästä Sampo-ohjelmasta. Häkkikohtainen rehunkulutus mitattiin päivittäin ja ketut punnittiin kolmen viikon välein vieroituksesta nahkontaan ulottuvalla jaksolla. Rehuhyötysuhde laskettiin kasvun ja häkkikohtaisen rehunkulutuksen perusteella (g kasvu/g rehunkulutus). Gradeeraus eli elävän eläimen arvostelu tehtiin noin kuukausi ennen nahkontaa. Aineisto analysoitiin restricted maximum likelihood -menetelmällä (DMU-ohjelma) soveltaen eläinmallia.

Sinikettujen rehuhyötysuhteen periytymisasteet olivat keskinkertaisia $(0,36-0,43)$, mutta todennäköisesti hieman yliarvioituja. Tämä tarkoittaa, että valinnalla voidaan parantaa sinikettujen rehuhyötysuhdetta. Hyvä rehuhyötysuhde oli, ainakin taloudellisessa mielessä, suotuisasti korreloitunut nopean kasvun kanssa. Pelkän rehunkulutuksen perusteella näyttäisi kuitenkin olevan vaikea jalostaa siniketun rehuhyötysuhdetta, sillä päivittäisen rehunkulutuksen ja rehuhyötysuhteen väliset fenotyyppiset ja geneettiset korrelaatiot olivat matalia. Toisaalta tämä merkitsee sitä, että rehuhyötysuhdetta voidaan todennäköisesti parantaa ilman, että rehunkulutus lisääntyy. Käytännön olosuhteissa rehuhyötysuhteen mittaaminen vaatii kuitenkin rehunkulutuksen seurannan lisäksi eläinten punnituksia vähintään kaksi kertaa kasvatuskauden aikana.

Gradeerausajankohtana mitatun rehuhyötysuhteen geneettiset ja fenotyyppiset korrelaatiot kokoominaisuuksien kanssa olivat matalammat ja suotuisammat kuin nahkonta-ajankohtana mitatut korrelaatiot. Nykyisessä valintaohjelmassa siniketun kokoa ei haluta enää voimakkaasti lisätä. Eläimen suuremman koon jalostaminen ja/tai eläimen lihottaminen äärimittoihin johtaa erilaisiin hyvinvointi ongelmiin ja mm. kettujen pentutulos ja jalkaterveys ovat heikentyneet viime vuosina. Toisaalta kuitenkin eläimen nopeakasvuisuus liittyi hyvään rehuhyötysuhteeseen ja suureen kokoon, joten todennäköisesti eläinten koon kasvamista ei voida täysin välttää, mikäli rehuhyötysuhdetta halutaan parantaa.

Asiasanat: turkiseläimet, sinikettu, alopex lagopus, rehuhyötysuhde, periytymisaste, korrelaatio 


\section{Johdanto}

Rehu on turkistuotannon suurin kustannustekijä ja siinä saavutettavat säästöt alentavat merkittävästi raakanahkojen tuotantokustannuksia. Kotieläinten parempi rehuhyötysuhde vähentää myös ympäristöpäästöjä. Sinikettujen rehunkulutuksesta ja rehuhyötysuhteesta saatava tutkimustieto on ainutlaatuista, sillä vastaavanlaista laajaa ruokinta- ja kasvatusaineistoa, jota tarvitaan sinikettujen rehuhyötysuhteen varianssikomponenttien ja perinnöllisten tunnuslukujen laskentaan, ei ole aiemmin ollut saatavilla. Sinikettujen rehuhyötysuhde tai rehunkulutus eivät ole nykyisissä valintaohjelmissa mukana jalostettavina ominaisuuksina. Tämä johtuu siitä, että yksilöllistä rehunkulutusta on ollut vaikea mitata suuresta määrästä sinikettuja. Rehunkulutustietojen kerääminen on tullut mahdolliseksi uusien yksilöllistä rehunkulutusta seuraavien automaattisten ruokintajärjestelmien myötä. Rehuhyötysuhteen laskeminen vaatii rehunkulutustietojen lisäksi tiedon eläimen painonmuutoksesta vastaavana ajankohtana. Tutkimuksen tavoitteena on arvioida rehun hyväksikäytön ja kasvunopeuden periytyvyys ja perinnölliset yhteydet eläimen kokoon.

\section{Aineisto ja menetelmät}

Tutkimusaineistona käytettiin MTT turkistalouden tutkimusaseman ja Keski-Pohjanmaan maaseutuopiston Kannuksen yksikön koulutiloilla keväällä 2005 ja 2006 syntyneitä pentuja. Kaiken kaikkiaan aineisto koostui noin 2076 ketusta, jotka olivat 29 eri isän ja 241 eri emän jälkeläisiä. Puolet emoista oli yksivuotiaita ja toinen puoli 2-3-vuotiaita naaraita. Tutkimuksessa käytetty laajempi sukulaisuusaineisto saatiin Suomen Turkiseläinten Kasvattajain Liitto ry:n (STKL) ylläpitämästä Sampo-ohjelmasta. Sampoon tallennetussa sukulaisuustiedostossa on yhteensä 21296 ketun tiedot, jotka ovat syntyneet 1981-2006 välisenä aikana MTT:n Kannuksen tilalla.

Kokeeseen valitut pennut syntyivät toukokuun alun ja kesäkuun puolivälin välisenä aikana (6.5.19.6). Aikaisin keväällä syntyneitä pentuja aineistossa oli kuitenkin vain muutamia kymmeniä (74kpl). Pääasiassa pennut olivat syntyneet toukokuun puolivälin ja kesäkuun puolivälin välisenä aikana. Syntymäajankohta jaettiin neljään luokkaan vastaavalla luokituksella kuin nykyisessä sinikettujen jalostusohjelmassa ( $(1=104-129,2=130-144,3=145-160$ ja $4=161-180$ päivää vuoden alusta $)$. Vieroituksen jälkeen elokuun puolivälissä ketut siirtyivät pareittain kasvatushäkkeihin ja ruokintatietojen tallentaminen aloitettiin. Pennut olivat kokeen alkaessa 15.8. kasvukaudella 2005 keskimäärin 74 päivän ikäisiä (57-91 päivää) ja vuonna 2006 keskimäärin 84 päivän ikäisiä (60-101 vuorokautta). Pentueista muodostettiin uros-uros, uros-naaras ja naaras-naaras täyssisarpareja, jotta eläinten sukupuolen vaikutus saatiin huomioitua ilman, että sen vaikutus menisi päällekkäin mahdollisen häkkivaikutuksen kanssa. Uros-naaras pareja oli lähes puolet kaikista pareista. Toinen puolikas jakautui melko tasaisesti uros-uros ja naara-naaras pareihin. Kasvatusolosuhteiksi oli valittu kaksi varjotaloa ja yksi hallirakennus. Hallissa kasvatettiin $60 \%$ ketuista ja loput jakautuivat tasaisesti kahteen varjotaloon.

Häkkikohtainen kettuparin rehunkulutus (DFI) mitattiin päivittäin. Häkkikohtainen rehunkulutuksen seuranta perustui Farm Pilot -ruokintajärjestelmään (Tanska), joka annosteli ja rekisteröi päivittäin kettuparille annetun rehumäärän. Häkkikohtainen rehumäärä ohjelmoitiin laitteen muistiin uudelleen päivittäin rehujäämien ja vähentyneen tai lisääntyneen rehunkulutuksen mukaan. Rehunkulutuksen seurantaa tehtiin vieroituksesta nahkontaan. Nahkottaessa ketut olivat 156-227 päivän ikäisiä. Keskimääräinen nahkontaikä koko aineistosta laskettuna oli 189 vuorokautta.

Siniketut ruokittiin kaupallisella ketunrehulla (Kannuksen Minkinrehu Oy). Rehun raaka-aineina käytettiin mm. silakkaa, teurassivutuotteita, kypsennettyä ohraa ja vehnää, kalasivutuotetta, turkiseläinruhomassaa, valkuaistiivistettä, lihaluujauhoa, kalajauhoa, happosäilöttyä kalaa ja turkiseläinrasvaa. Rehusta tehtiin säännöllisesti rehuanalyysit STKL ry:n turkiseläinlaboratoriossa. Rehun kuiva-aineen määritys tehtiin MTT:n turkistilalla Kannuksessa gravimetrisesti. Rehut kuivattiin $103{ }^{\circ} \mathrm{C}$ lämpötilassa 19 tuntia. Typpi määritettiin Turkiseläinlaboratoriossa Kjeldahl-tekniikalla (sisäinen menetelmä KEMI I). Raakarasva (KEMI 2, HCl-hydrolyysi ja soxhleuutto), tuhkapitoisuus (KEMI 4, ) ja pH (KEMI 5) määritettiin Turkiseläinlaboratorion sisäisillä menetelmillä. Raakahiilihydraattien määrä laskettiin seuraavasti: 1000(tuhka-raakavalkuainen-raakarasva-vesi) (sisäinen menetelmä KEMIA 6). Kannuksen rehun analysoitu koostumus kokeen aikana on esitetty taulukossa 1.

Siniketut punnittiin kolmen viikon välein vieroituksesta nahkontaan. Ketut punnittiin ensimmäisen kerran vieroituksen yhteydessä (15.8.) ja neljä kertaa kasvukauden aikana (5.9., 26.9., 17.-18.10. ja 7.-8.11). Viimeinen punnitus tehtiin nahkonnan yhteydessä. Keskimääräinen kasvunopeus (DG g/pv) laskettiin kaavalla: jakson loppupaino - jakson alkupaino/kasvatuspäivien lukumäärä. Rehuhyötysuhde (g kasvu/g rehun- 
kulutus) laskettiin kasvun ja häkkikohtaisen rehunkulutuksen avulla: rehuhyötysuhde (FE) = häkkiparin kasvu jaksolla, g / häkkiparin rehunkulutus jaksolla, g tai $g$ KA. Rehuhyötysuhteet laskettiin vertailun vuoksi sekä tuoreen rehun $(\mathrm{FE})$ että kuiva-aineen $\left(\mathrm{FE}_{\mathrm{KA}}\right)$ perusteella. Gradeeraus eli elävän eläimen arvostelu tehtiin noin kuukausi ennen nahkontaa (7.-16.11.2005 ja 23.-26.10.2006). Silmävaraisesti arvioituna eläimen koko muodostuu sekä painosta että pituudesta. Eläimen koon arvioinnissa luokka 1 on pienin ja luokka 5 suurin. Gradeerauskokoa arvosteltaessa tarhan keskiarvon tulisi olla 3 joka vuosi.

Varianssi- ja kovarianssikomponentit arvioitiin yhden ominaisuuden eläinmallilla DMU-ohjelmalla (Madsen ja Jensen 2000), joka perustuu restricted maximum likelihood (REML) -menetelmään. Talovuosi, sukupuoli, häkkipari, syntymäajankohta ja emän ikä olivat kiinteitä tekijöitä. Pentue-, eläin- ja jäännöstekijä olivat satunnaistekijöitä.

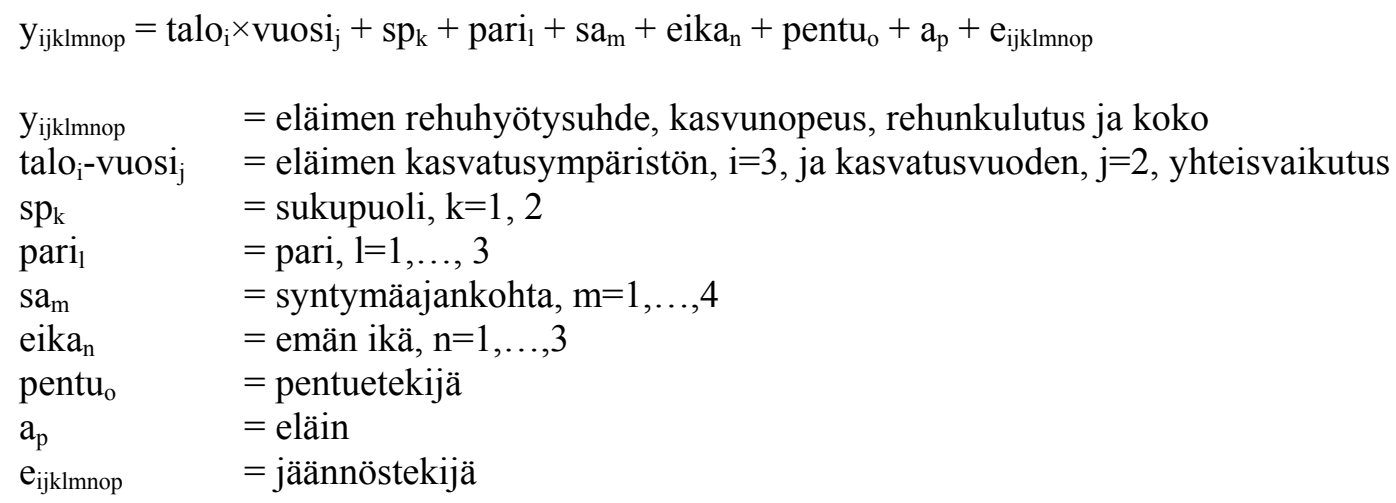

Periytymisaste $\left(h^{2}\right)$ ja pentuetekijän vaihtelun osuus $\left(c^{2}\right)$ laskettiin kaavalla $h^{2}=\sigma_{a}^{2} /\left(\sigma_{a}^{2}+\sigma_{c}^{2}+\sigma_{e}^{2}\right)$ ja $\mathrm{c}^{2}=$ $\sigma_{a}^{2} /\left(\sigma_{a}^{2}+\sigma_{c}^{2}+\sigma_{e}^{2}\right)$, missä $\sigma_{a}^{2}$ on additiivinen geneettinen varianssi, $\sigma_{c}^{2}$ on pentuetekijän varianssi ja $\sigma_{e}^{2}$ on jäännösvarianssi. Ominaisuuksien väliset geneettiset korrelaatiot laskettiin kahden ominaisuuden mallilla.

\section{Tulokset ja tulosten tarkastelu}

Ominaisuuksien keskiarvot, hajonnat, vaihtelukerroin, minimit ja maksimit ovat taulukossa 2. Pentujen vieroituspainoissa oli ikäerosta johtuen suuri hajonta heti ensimmäisessä punnituksessa. Keskimääräinen vieroituspaino oli 4,3 kg, mutta pienimmät ketut olivat 1,5 kg:n ja suurimmat yli $7 \mathrm{~kg}: \mathrm{n}$ painoisia. Elopainon hajonta kasvoi iän myötä, mikä liittyi osittain painon keskiarvon kasvamiseen. Suurin kettu painoi nahkottaessa 21,7 kg, kun keskimääräinen nahkontapaino oli 13,6 kg. Myös kettujen kasvunopeudessa oli suurta vaihtelua - suurten kettujen kasvuvauhti oli lähes kolminkertainen pienimpiin kettuihin verrattuna. Keskimääräinen kasvunopeus vieroituksesta nahkontaan oli $85 \mathrm{~g} / \mathrm{d}$ ja vieroituksesta gradeerausajankohtaan laskettuna $92 \mathrm{~g} / \mathrm{d}$. Urosten keskimääräinen päiväkasvuvauhti noin $10 \mathrm{~g}$ päivässä suurempi kuin naarailla. Syntymäajankohdalla oli luonnollisesti selkeä ja johdonmukainen vaikutus kasvunopeuteen. Aikaisin syntyneiden eläinten kasvunopeus oli gradeeraus- ja nahkontahetkellä jo selvästi hitaampaa kuin myöhään syntyneillä. Emän iän vaikutus pentujen kasvunopeuteen oli myös merkittävä. Nuorten naaraiden pentujen kasvunopeus oli suurempi kuin vanhempien naaraiden. Tämä on todennäköisesti seurausta nuorten naaraiden pienemmästä pentuekoosta, jolloin pentujen sisäinen kilpailu ravinnosta on vähäisempää. Eläinten gradeerauskoon keskiarvo oli 3,7, mikä oli melko lähellä odotettua keskiarvoa (3). Sukupuolen vaikutus eläimen gradeerauskokoon oli selvä. Urosten koon keskiarvo oli 4,2 ja naaraiden 3,2, joten urokset olivat keskimäärin yhtä kokoluokkaa suurempia kuin naaraat. Häkkiparien kokoerot gradeeraushetkellä olivat pienet. Parhaiten kasvoivat kuitenkin uros-naarasparit, jotka olivat keskimäärin 0,4 kokoluokkaa suurempia kuin naaras-naaras parit ja 0,2 luokkaa suurempia kuin uros-uros parit.

Suuret erot kettujen painoissa ja kasvunopeudessa näkyvät luonnollisesti myös rehunkulutuksessa ja rehuhyötysuhteessa, mutta vaihtelu ei ollut näissä ominaisuuksissa suhteessa aivan yhtä suurta kuin painossa tai kasvunopeudessa. Sinikettuparin keskimääräinen rehunkulutus koko tutkimusjaksolla oli $1,7 \mathrm{~kg}$ päivässä ja energiankulutus 12,6 MJ ME päivässä. Siniketut kasvoivat keskimäärin 98 grammaa kilolla rehua vieroituksesta nahkontaan ulottuvalla jaksolla (totFE). Rehuhyötysuhteen vaihteluväli jaksolla oli 0,067-0,138. Vieroituksesta gradeeraukseen laskettu rehuhyötysuhde (gFE) oli hieman korkeampi. Rehuhyötysuhde heikkeni kasvukauden loppua kohden ollen lähes puolta pienempi kasvatuskauden lopussa. Uros-uros ja uros-naaras parien rehuhyötysuhde oli tilastollisesti merkitsevästi parempi kuin naaras-naaras 
häkkipareilla. Uros-uros tai uros-naaras häkkiparien välillä ei ollut merkittävää eroa.

Ominaisuuksien periytymisasteet on esitetty taulukossa 3. Eläimen kokoa kuvaavien muuttujien periytymisasteet olivat keskinkertaisia tai korkeita. Eläimen koon periytymisaste gradeeraushetkellä oli 0,34 ja eläimen nahoituspainon 0,53. Eläimen gradeerauskoon periytymisaste oli korkeampi kuin Peuran et al. (2004) tutkimuksessa $(0,25)$. Pentuetekijän selitti kasvatuskauden lopussa mitattujen kokomuuttujien vaihtelusta $13-20 \%$. Pentuetekijän vaikutus oli suurimmillaan elopainoon heti vieroitusvaiheessa ja sen osuus laski eläinten kasvaessa.

Rehuhyötysuhteen $(0,36-0,43)$, joka kuvastaa tässä tutkimuksessa myös eläimen maksimaalista syöntikykyä, ja kasvunopeuden $(0,33-0,48)$ periytymisasteet olivat samaa suuruusluokkaa ollen keskikertaisia tai korkeita. Pentuetekijän vaikutus oli kuitenkin pienempi kasvunopeuteen kuin rehuhyötysuhteeseen, missä sen osuus vaihtelusta oli $25-27 \%$. Koko kasvatusjaksolle vieroituksesta nahkontaan laskettu rehuhyötysuhteen periytymisaste oli viisi prosenttiyksikköä korkeampi kuin vieroituksesta gradeerausajankohtaan laskettu rehuhyötysuhde. Rehuhyötysuhde laskettiin vertailun vuoksi sekä tuoreen rehun että kuiva-aineen perusteella. Näiden periytymisasteet olivat samansuuruisia, joten rehuhyötysuhde voidaan laskea suoraan joko rehunkulutuksen perusteella tai rehun kuiva-aineesta. Häkkiparille lasketun rehuhyötysuhteen ja rehunkulutuksen periytymisasteen arviot ovat kuitenkin todennäköisesti yliarvioitu, koska ne on alustavasti laskettu yksilötulosten tapaan. Kokeesta mitattu rehuhyötysuhteen tulos oli kuitenkin määritetty parille, ei yksilölle, jolloin sitä ei voi luotettavasti analysoida yksilötulosten tapaan (Kovac \& Groeneveld 1990, Sevón-Aimonen ym. 1995). Tutkimusta jatketaan vielä mahdollisimman luotettavien h2-arvioiden laskemiseksi.

Geneettiset ja fenotyyppiset korrelaatiot rehuhyötysuhteen, rehunkulutuksen, kasvunopeuden ja eläimen koon välillä on esitetty taulukossa 4 . Tämän kokoisesta aineistosta lasketut geneettisten korrelaatioiden keskivirheet tulevat melko korkeiksi etenkin matalien korrelaatioiden kohdalla, mutta tulokset antavat kuitenkin viitteitä ominaisuuksien välisistä yhteyksistä. Rehuhyötysuhde, rehunkulutus ja kasvunopeus laskettiin vertailun vuoksi sekä vieroituksesta gradeerausajankohtaan että koko kasvatuskaudelle. Gradeerausajankohtana mitattujen ominaisuuksien sisäiset geneettiset korrelaatiot vastaaviin nahkontaajankohtana määritettyihin mittaustuloksiin olivat korkeita (yli 0,90). Sen sijaan rehuhyötysuhteen ja muiden ominaisuuksien väliset geneettiset korrelaatiot olivat matalampia gradeerausajankohtana kuin nahkonta-ajankohtana.

Päivittäisen rehunkulutuksen ja rehuhyötysuhteen välinen geneettinen korrelaatio oli melko matala ja keskivirheet suuria. Vieroituksesta gradeerausajankohtaan määritetyn rehunkulutuksen ja rehuhyötysuhteen geneettinen $(-0,15)$ ja fenotyyppinen $(-0,16)$ korrelaatio olivat negatiivisia, kun taas vieroituksesta nahkonta-ajankohtaan määritetyn rehunkulutuksen ja rehuhyötysuhteen geneettinen $(0,29)$ ja fenotyyppinen $(0,10)$ korrelaatio olivat positiivisia. Kettujen rehunkulutus nousi merkittävästi juuri gradeerausajankohdan aikaan, minkä vuoksi kettujen paino nousi vielä viimeisellä jaksolla suhteellisen paljon lihomisen vuoksi. Tämä saattaa osaltaan selittää, miksi rehuhyötysuhteen ja rehunkulutuksen välinen negatiivien korrelaatio muuttui positiiviseksi koko kasvatusjaksoa tarkasteltaessa.

Voimakkain geneettinen ja fenotyyppinen korrelaatio rehuhyötysuhteella oli kasvunopeuden kanssa eli nopeasti kasvavilla eläimillä on myös hyvä rehun hyväksikäyttökyky. Rehuhyötysuhteen ja kasvunopeuden välinen geneettinen $(0,88)$ ja fenotyyppinen $(0,58)$ korrelaatio olivat korkeita etenkin nahkontaajankohtana. Gradeerausajankohtana määritetty rehuhyötysuhteen ja kasvunopeuden geneettinen $(0,63)$ ja fenotyyppinen $(0,47)$ korrelaatio olivat hieman matalampia. Kasvunopeuden geneettiset korrelaatiot olivat korkeita $(0,75-0,94)$ rehuhyötysuhteen lisäksi rehunkulutuksen, painon ja gradeerauskoon välillä. Vastaavat fenotyyppiset korrelaatiot olivat keskinkertaisia tai korkeita.

Rehuhyötysuhteen ja eläimen nahkontapainon välinen positiivinen geneettinen korrelaatio oli melko korkea $(0,64)$, mutta rehuhyötysuhteen ja gradeerauspainon välinen geneettinen korrelaatio oli huomattavasti matalampi $(0,21)$. Rehuhyötysuhteen ja eläimen gradeerauskokoon välillä oli negatiivinen geneettinen korrelaatio $(-0,08)$, joka tosin oli matala ja sen keskivirhe suuri. Vastaava fenotyyppinen korrelaatio oli positiivinen $(0,06)$. Nahkonta-ajankohtana tarkasteltuna rehuhyötysuhteen ja gradeerauskoon geneettinen $(0,17)$ ja fenotyyppinen $(0,11)$ korrelaatio olivat molemmat positiivisia, mutta kuitenkin melko matalia.

\section{Johtopäätökset}

Sinikettujen rehuhyötysuhteen alustavat periytymisasteiden arviot viittaavat siihen, että kyseessä on vähin- 
täänkin keskinkertaisesti periytyvä ominaisuus. Tämä tarkoittaa, että valinnalla voidaan parantaa sinikettujen rehuhyötysuhdetta. Rehuhyötysuhteen paraneminen ja tarkentunut ruokinta parantavat tuotannon taloudellisuutta sen lisäksi, että ympäristöön kohdistuva kuormitus pienenee. Hyvä rehuhyötysuhde oli, ainakin taloudellisessa mielessä, suotuisasti korreloitunut nopean kasvun kanssa. Pelkän rehunkulutuksen perusteella näyttäisi kuitenkin olevan vaikea jalostaa siniketun rehuhyötysuhdetta, sillä päivittäisen rehunkulutuksen ja rehuhyötysuhteen välinen geneettinen korrelaatio oli melko matala. Toisaalta tämä merkitsee sitä, että rehuhyötysuhdetta voidaan todennäköisesti parantaa ilman, että rehunkulutus lisääntyy. Käytännön olosuhteissa rehuhyötysuhteen mittaaminen vaatii kuitenkin rehunkulutuksen seurannan lisäksi eläinten punnituksia vähintään kaksi kertaa kasvatuskauden aikana.

Rehuhyötysuhde laskettiin vertailun vuoksi sekä vieroituksesta gradeerausajankohtaan että koko kasvatuskaudelle. Noin kuukautta ennen nahkontaa gradeerauksen yhteydessä tehdään jalostuseläinten valinnat, joten eläimen rehuhyötysuhde olisi hyvä olla tiedossa jo tässä vaiheessa, mikäli ominaisuuden suhteen halutaan tehdä valintaa. Gradeerausajankohtana mitatun rehuhyötysuhteen geneettiset ja fenotyyppiset korrelaatiot koko-ominaisuuksien kanssa olivat matalammat ja suotuisammat kuin nahkontaajankohtana mitatut korrelaatiot. Nykyisessä valintaohjelmassa siniketun kokoa ei haluta enää voimakkaasti kasvattaa. Eläimen suuremman koon jalostaminen ja/tai eläimen lihottaminen äärimittoihin johtaa erilaisiin hyvinvointi ongelmiin ja mm. kettujen hedelmällisyys ja jalkaterveys ovat heikentyneet viime vuosina (Peura 2004, Keski-Nisula 2006). Toisaalta kuitenkin eläimen nopeakasvuisuus liittyi hyvään rehuhyötysuhteeseen ja suureen kokoon, joten todennäköisesti eläinten koon kasvamista ei voida täysin välttää.

Taulukko 1. Rehun keskimääräinen koostumus kasvatuskausilla 2005 ja 2006.

\begin{tabular}{lrr} 
& $\mathbf{2 0 0 5}$ & $\mathbf{2 0 0 6}$ \\
& $\mathrm{n}=9$ & $\mathrm{n}=7$ \\
\hline Kuiva-aine g/kg & 43,9 & 42,2 \\
Tuhka & 4,2 & 4,1 \\
Raakavalkuainen & 13,1 & 11,9 \\
Raakarasva & 11,5 & 12,5 \\
Raakahiilihydraatit & 15,0 & 13,8 \\
Muuntokelpoinen energia MJ/kg KA ${ }^{(1}$ & 17,1 & 17,7 \\
Sulavaa valkuaista g/kg KA & 237,4 & 217,7 \\
Muuntokelpoisesta energiasta: & & \\
Raakarasva \% & 52,8 & 56,8 \\
Raakavalkuainen \% & 25,9 & 23,4 \\
Raakahiilihydraatit \% & 21,4 & 19,9 \\
\hline 1) Muuntokelpoinen energia ME (MJ) = (18,8 SRV + 38,9 SRR + 17,2 SRH)/1000, missä SRV = sulava raaka- \\
valkuainen, g/kg KA, SRR = sulava raakarasva, g/kg KA, SRH = sulavat raakahiilihydraatit, g/kg KA.
\end{tabular}


Taulukko 2. Tutkittavien ominaisuuksien havaintojen lukumäärät (n), keskiarvot (ka), keskihajonta $(\sigma)$, vaihtelukerroin (cv) sekä minimit ja maksimit.

\begin{tabular}{|c|c|c|c|c|c|c|}
\hline & $\mathbf{n}$ & ka & $\boldsymbol{\sigma}$ & cv & $\min$ & $\max$ \\
\hline Vieroituspaino, $\mathrm{kg}$ (15.8.) & 2076 & 4,28 & 11,41 & 26,65 & 1,56 & 7,72 \\
\hline Gradeerauspaino, kg (7.-8.11.) & 2063 & 12,06 & 15,81 & 13,10 & 6,20 & 18,16 \\
\hline Nahkontapaino, kg & 2058 & 13,61 & 20,14 & 14,80 & 7,82 & 21,66 \\
\hline Eläimen gradeerauskoko & 2060 & 3,70 & 0,90 & 24,34 & 1 & 5 \\
\hline gDG, kasvunopeus g/pv & 2057 & 92,00 & 12,96 & 14,08 & 47,80 & 139,30 \\
\hline totDG, kasvunopeus g/pv & 2057 & 85,20 & 13,99 & 16,42 & 38,60 & 139,50 \\
\hline gDFI, rehunkulutus g/pari/pv & 1007 & 1757 & 158,10 & 9,00 & 1305 & 2198 \\
\hline $\mathrm{gDFI}_{\mathrm{KA}}, \mathrm{g} \mathrm{KA} /$ pari/pv & 1008 & 747 & 67,70 & 9,07 & 558 & 968 \\
\hline totDFI, rehunkulutus g/pari/pv & 1001 & 1714 & 157,66 & 9,20 & 1238 & 2208 \\
\hline totDFI $_{\mathrm{KA}}, \mathrm{g} \mathrm{KA} /$ pari/pv & 1001 & 721 & 62,38 & 8,65 & 508 & 905 \\
\hline Energiankulutus tot, MJ ME/pari/pv & 1001 & 12,60 & 1,10 & 8,72 & 8,83 & 15,91 \\
\hline gFE, g kasvu/g rehua & 1008 & 0,105 & 0,01 & 9,48 & 0,067 & 0,138 \\
\hline $\mathrm{gFE}_{\mathrm{KA}}, \mathrm{g} \mathrm{kasvu} / \mathrm{g} \mathrm{KA}$ & 1007 & 0,249 & 0,02 & 9,25 & 0,1633 & 0,336 \\
\hline totFE, g kasvu/g rehua & 1001 & 0,098 & 0,01 & 10,25 & 0,060 & 0,125 \\
\hline totFE $E_{\mathrm{KA}}, \mathrm{g}$ kasvu/g KA & 1001 & 0,233 & 0,02 & 10,38 & 0,147 & 0,305 \\
\hline
\end{tabular}

$\mathrm{g}=$ vieroituksesta (15.8.) gradeeraukseen (7.-8.11.) ulottuva tutkimusjakso

tot $=$ vieroituksesta (15.8.) nahkontaan ulottuva tutkimusjakso

$\mathrm{KA}=$ kuiva-aine, $\mathrm{FE}=$ rehuhyötysuhde

Taulukko 3: Ominaisuuksien fenotyypiset varianssit $\left(\sigma_{P}^{2}\right)$, pentuetekijän osuus fentotyyppisestä varianssista $\left(c^{2}\right)$ keskivirheineen (s.e.) sekä periytymisasteet $\left(h^{2}\right)$ keskivirheineen (s.e.).

\begin{tabular}{|c|c|c|c|}
\hline & $\sigma_{P}^{2}$ & $c^{2} \pm$ s.e. & $h^{2} \pm$ s.e. \\
\hline Eläimen gradeerauskoko (gSI) & 0,56 & $0,15 \pm 0,03$ & $0,34 \pm 0,09$ \\
\hline Vieroituspaino1 & 0,49 & $0,48 \pm 0,04$ & $0,37 \pm 0,08$ \\
\hline Gradeerauspaino & 1,87 & $0,21 \pm 0,04$ & $0,40 \pm 0,10$ \\
\hline Nahoituspaino & 2,91 & $0,13 \pm 0,03$ & $0,53 \pm 0,10$ \\
\hline Kasvunopeus vieroituksesta gradeeraukseen (gDG) & 149,25 & $0,14 \pm 0,03$ & $0,33 \pm 0,09$ \\
\hline Kasvunopeus vieroituksesta nahkontaan (totDG) & 166,68 & $0,11 \pm 0,03$ & $0,48 \pm 0,09$ \\
\hline Rehunkulutus vieroituksesta gradeeraukseen (gDFI) & 24616,60 & $0,34 \pm 0,04$ & $0,42 \pm 0,09$ \\
\hline Rehunkulutus KA:na vieroituksesta gradeeraukseen $\left(\mathrm{gDFI}_{\mathrm{KA}}\right)$ & 4470,42 & $0,34 \pm 0,04$ & $0,43 \pm 0,09$ \\
\hline Rehunkulutus, tot (totDFI) & 22666,40 & $0,31 \pm 0,04$ & $0,41 \pm 0,09$ \\
\hline Rehunkulutus KA:na, tot (totDFI $\mathrm{KA}_{\text {) }}$ & 3991,36 & $0,31 \pm 0,04$ & $0,43 \pm 0,09$ \\
\hline Rehuhyötysuhde vieroituksesta gradeeraukseen ( $\mathrm{gFE})$ & 0,000067 & $0,25 \pm 0,04$ & $0,37 \pm 0,09$ \\
\hline Rehuhyötysuhde vieroituksesta gradeeraukseen ( $\left.\mathrm{gFE}_{\mathrm{KA}}\right)$ & 0,000376 & $0,25 \pm 0,04$ & $0,36 \pm 0,09$ \\
\hline Rehuhyötysuhde vieroituksesta nahkontaan, (totFE) & 0,000064 & $0,27 \pm 0,04$ & $0,42 \pm 0,08$ \\
\hline Rehuhyötysuhde vieroituksesta nahkontaan, (totFE $E_{\mathrm{KA}}$ & 0,000367 & $0,27 \pm 0,04$ & $0,43 \pm 0,08$ \\
\hline
\end{tabular}

Taulukko 4. Rehuhyötysuhteen, rehunkulutuksen, kasvunopeuden ja koon fenotyyppiset $\left(\mathrm{r}_{\mathrm{p}}\right)$ ja geneettiset $\left(\mathrm{r}_{\mathrm{g}}\right)$ korrelaatiot keskivirheineen (s.e.).

\begin{tabular}{|c|c|c|c|c|c|c|c|c|c|}
\hline & \multicolumn{2}{|c|}{ gFE } & \multicolumn{2}{|r|}{ gDG } & & \multicolumn{2}{|c|}{ totFE } & \multicolumn{2}{|c|}{ totDG } \\
\hline & $\mathbf{r}_{\mathrm{p}}$ & $\mathbf{r}_{\mathrm{g}} \pm$ s.e. & $\mathbf{r}_{\mathrm{p}}$ & $\mathbf{r}_{\mathrm{g}} \pm$ s.e. & & $\mathbf{r}_{\mathrm{p}}$ & $\mathbf{r}_{\mathrm{g}} \pm$ s.e. & $\mathbf{r}_{\mathbf{p}}$ & $\mathbf{r}_{\mathrm{g}} \pm$ s.e. \\
\hline gDFI & $-0,16$ & $-0,15 \pm 0,18$ & 0,58 & $0,75 \pm 0,09$ & totDFI & 0,10 & $0,29 \pm 0,17$ & 0,65 & $0,85 \pm 0,06$ \\
\hline totFE & 0,78 & $0,98 \pm 0,02$ & 0,45 & $0,86 \pm 0,12$ & totFE & & & 0,58 & $0,88 \pm 0,06$ \\
\hline gDG & 0,47 & $0,63 \pm 0,14$ & & & totDG & 0,58 & $0,88 \pm 0,06$ & & \\
\hline Grad.paino & 0,16 & $0,21 \pm 0,19$ & 0,87 & $0,92 \pm 0,03$ & Nahoit.paino & 0,40 & $0,64 \pm 0,12$ & 0,90 & $0,94 \pm 0,02$ \\
\hline gSI & 0,06 & $-0,08 \pm 0,19$ & 0,62 & $0,85 \pm 0,07$ & gSI & 0,11 & $0,17 \pm 0,18$ & 0,44 & $0,76 \pm 0,09$ \\
\hline
\end{tabular}




\section{Kirjallisuus}

Keski-Nisula, S. 2006. Siniketun tuotanto-ominaisuuksiin vaikuttavien kromosomialueiden kartoitus. Pro Gradu -työ. Helsingin yliopiston kotieläintieteen laitoksen julkaisuja $82.37 \mathrm{~s}$.

Kovac, M \& Groeneveld, E. 1990. Multivariate genetic evaluation in swine comgining data from different testing schemes. J. Anim. Sci. 68: 3507-3522.

Madsen, P. \& Jensen, J. 2000. Users guide to DMU, a package for analysing Multivariate Mixed Models. Danish Institute of Agricultural Sciences. Tjele. Denmark. 22 p.

Peura, J., Strandén, I. \& Smeds, K. 2004. Genetics of litter size, age at first insemination and animal size in blue fox (Alopex lagopus). In B. Urlings, B. Spruijt, M. Ruis, L. Boekhorst (Eds.), Proceedings of the VIII International Scientific Congress in Fur Animal Production, 15.-18 September (2004), 'SHertogenbosch, The Netherlands, Part IV-3RP. Scientifur, 28, 206-210.

Peura, J., Strandén, I. \& Mäntysaari, E. 2005. Genetic parameters in Finnish blue fox population: Pelt character and live animal grading traits. Acta Agriculturae Scand Section A, 55: 137-144.

Sevón-Aimonen, M.-L., Mäntysaari, E. \& Haltia, S. 1995. Periytymisasteiden arviointi sikojen täyssisarryhmäaineistosta. In: Agro-Food '95 : tieto turvaa tulevaisuuden : Tampere 13.-15.11.1995, Tamperetalo. Helsinki: Agro-Food ry. p. B25. (Posteritiivistelmä). 